\title{
PENGEMBANGAN MEDIA PEMBELAJARAN MULTIMEDIA INTERAKTIF PADA KELAS XI MATA PELAJARAN BIOLOGI DENGAN MATERI "SISTEM SIRKULASI PADA MANUSIA DAN SISTEM PENCERNAAN MAKANAN" DI SMA NEGERI 2 SINGARAJA
}

\author{
I Putu Novri Febrianto $^{1}$, Dr. phil. Dessy Seri Wahyuni ${ }^{2}$, Nyoman Sugihartini ${ }^{3}$ \\ Program Studi Pendidikan Teknik Informatika Jurusan Teknik Informatika, Fakultas Teknik dan Kejuruan Universitas Pendidikan \\ Ganesha, Singaraja, Bali \\ E-mail :febrianto.putu@undiksha.ac.id, seri.wahyuni@undiksha.ac.id ${ }^{2}$, sugihartini@undiksha.ac.id ${ }^{3}$
}

\begin{abstract}
Abstrak- Belajar dan media pembelajaran memiliki kaitan yang sangat erat, proses pembelajaran tidak akan berjalan dengan lancar tanpa adanya media pembelajaran yang tepat. Media pembelajaran yang digunakan di SMA N 2 Singaraja masih menggunakan metode ceramah dan teknik pembelajaran yang disampaikan oleh guru monoton, sehingga menyebabkan siswa cenderung bosan dan bersikap pasif pada proses pembelajaran. Tujuan dari penelitian pengembangan media ini adalah (1) sebagai penunjang proses pembelajaran siswa di SMA N 2 Singaraja dalam mempelajari materi biologi sistem sirkulasi pada manusia dan sistem pencernaan makanan. (2) mampu mengetahui respon siswa terhadap media pembelajaran interaktif biologi sistem sirkulasi pada manusia dan sistem pencernaan makanan. Pengembangan media pembelajaran interaktif mata pelajaran biologi sistem sirkulasi pada manusia dan sistem pencernaan makanan menggunakan model MDLC. Yang terdiri dari enam tahap yaitu Pengonsepan (Concept), Perancangan (Design), Pengumpulan Bahan (Material Collecting), Pembuatan (Assembly), Pengujian (Testing) dan Dsitribusi (Distribution). Media pembelajaran yang tepat harus menjadi kunci utama agar siswa mampu melakukan pembelajaran dengan semangat dan media pembelajaran ini akan dikombinasikan dengan konsep gamifikasi yang di akhir pembelajaran terdapat permainan kecil yang akan merefleksi pikiran siswa dengan cara bermain akan tetapi tidak sedikitpun mengurangi pembahasan dengan materi yang diawal dijelaskan.
\end{abstract}

Kata kunci : media pembelajaran, MDLC, sistem sirkulasi, sistem pencernaan.

Abstract-Learn and learned media have a very close relationship, the learned process will not run smoothly without the right learned media. The learned media used in SMA N 2 Singaraja still uses the monotonous lecture method and learning techniques conveyed by the teacher, which causes students to tend to be bored and be passive in the learning process. The objectives of this research on media development are (1) to support the learned process of students at SMA N 2 Singaraja in studying the biology of the human circulation system and the digestive system of food. (2) able to know the student's response to the interactive learned media of the circulatory system biology in humans and the digestive system of food. Development of interactive learned media in the biology of the circulatory system in humans and the digestive system using the MDLC model. Which consists of six stages, namely Concept, Design, Material Collecting, Assembly, Testing and Distribution. The right learned media must be the main key so that students are able to do learned with enthusiasm and this learned media will be combined with the concept of gamification which at the end of the lesson there is a small game that will reflect on the students' thoughts by played but not in the least reduced the discussion with the material that was initially explained.

Keywords: learning media, MDLC, circulation system, digestive system.

\section{PENDAHULUAN}

Perkembangan Ilmu Pengetahuan dan Teknologi (IPTEK) saat ini telah banyak memberikan kontribusi untuk kemajuan diberbagai bidang kehidupan. Salah satu dampak perkembangan teknologi adalah kemajuan di bidang pendidikan. Di Indonesia, teknologi pendidikan dimanfaatkan untuk pengembangan media pembelajaran, misalnya dengan mengembangkan materi ajar untuk siswa berbasis multimedia interaktif. Dengan adanya teknologi multimedia ini akan membuat proses pembelajaran semakin menyenangkan dan akan berdampak pada hasil belajar siswa. Media pembelajaran merupakan suatu alat atau perantara yang berguna untuk memudahkan proses belajar mengajar, dalam rangka mengefektifkan komunikasi antara guru dan siswa. Hal ini sangat membantu guru dalam mengajar dan memudahkan siswa menerima dan memahami pelajaran.

Teknologi multimedia memungkinkan terjadinya penyampaian informasi dengan lebih cepat, interaktif dan menarik. Pemanfaatannya telah diterapkan dalam berbagai 
bidang, seperti kesehatan, bisnis, hiburan, pendidikan dan berbagai kepentingan umum lainnya. Dalam bidang pendidikan, multimedia menjadi teknologi yang mempermudah proses pembelajaran. Dengan meng-gunakan multimedia, pengajar dapat menyajikan gambaran benda yang kompleks, berukuran sangat kecil atau sangat besar, serta peristiwa yang berlangsung sangat cepat dan berada di tempat yang jauh dalam bentuk yang menarik. Hal ini bermanfaat dalam meningkatkan imajinasi, pemahaman dan minat pelajar.

Mata pelajaran biologi merupakan salah satu cabang ilmu pengetahuan alam yang mempelajari tentang makhluk hidup, mulai dari makhluk hidup tingkat rendah hingga makhluk hidup tingkat tinggi. Biologi tidak hanya terdiri atas kumpulan pengetahuan atau berbagai macam fakta yang dihafal, melainkan pelajaran biologi membutuhkan kegiatan atau proses aktif menggunakan pikiran dalam memahami gejala-gejala alam. Pembelajaran biologi yang ideal haruslah sesuai dengan hakikat keilmuan biologi sebagai sains, yang meliputi objek dan permasalahan. Di samping itu, pembelajaran biologi hendaknya berpusat pada siswa (student centered) yang menekankan bahwa dalam pembelajaran siswa dapat membangun pengetahuannya

Hasil wawancara dengan guru bidang di SMA N 2 Singraja bahwa dalam proses pembelajaran Biologi guru masih menggunakan metode demonstrasi dalam mengajar belum adanya alat dan bahan yang sesuai dengan materi pembelajaran serta daya ingat anak yang rendah serta belum bisa berpikir abstrak sehingga anak susah untuk memahami materi. Hal ini menyebabkan proses kegiatan belajar mengajar kurang efektif dan tingkat pemahaman siswa dalam belajar siswa belum sesuai harapan. Selama ini penyajian materi "Sistem Sirkulasi pada Manusia \& Sistem Pencernaan Makanan" juga masih menggunakan metode konservatif, dan guru sudah menggunakan media seperti buku LKS terkait materi yang dijelaskan dengan menggunakan gambar tersebut sebagai permasalah yang harus dipecahkan oleh siswa, penyampaian materi tersebut tidak didukung dengan adanya fasilitas penunjang pembelajaran sehingga siswa sulit untuk memahami materi pada saat proses belajar mengajar.

Berdasarkan hasil dari wawancara yang telah di paparkan, dapat disimpulkan bahwa penyampaian materi "Sistem Sirkulasi pada Manusia \& Sistem Pencernaan Makanan" masih kurang efektif karena saat proses pembelajaran guru masih menggunakan metode pembelajaran yang belum tepat untuk pembelajaran Biologi dan media yang digunakan saat ini berupa buku LKS yang menjadi objek pada materi tersebut yang masih susah dimengerti oleh siswa. Sehingga dibutuhkan sebuah media pembelajaran yang menarik siswa untuk meningkatkan motivasi belajar dan adanya fasilitas bagi pengguna untuk berinteraksi dengan media.

Dari permasalahan yang terjadi, penulis dapat memberikan solusi yaitu sebuah media pembelajaran interaktif multimedia untuk mata pelajaran Biologi "Sistem Sirkulasi pada Manusia \& Sistem Pencernaan Makanan". Media pembelajaran yang tepat harus menjadi kunci utama agar siswa mampu melakukan pembelajaran dengan semangat. Multimedia pembelajaran interaktif sangat di butuhkan di sekolah karena dapat menjadi alat pengajaran elektronik yang dapat membantu pengajar dalam penyampaian materi pembelajaran. Dalam perancangan media ini menggabungkan dua media atau lebih seperti teks, grafik, gambar, audio, video, dan animasi secara terpadu yang akan dikombinasikan dengan konsep gamifikasi yang di akhir pembelajaran terdapat permainan kecil yang akan merefleksi pikiran siswa dengan cara bermain akan tetapi tidak sedikitpun mengurangi pembahasan dengan materi yang diawal dijelaskan. Berikutnya penelitian terkait yakni Penerapan Konsep Gamification untuk Mmeningkatkan Minat dan Partisipasi Siswa pada Mata Pelajaran Geografi di SMA NEGERI 2 SALATIGA" Mata pelajaran Geografi merupakan salah satu pelajaran yang terdiri dari banyak materi. Berdasarkan pembahasan analisis data yang telah dilakukan dalam penelitian maka dapat disimpulkan sebagai berikut: Penggunaan konsep pembelajaran Gamification dapat meningkatkan minat dan partisipasi belajar siswa pada mata pelajaran Geografi kelas X5 di SMA Negeri 2 Salatiga Semester I Tahun Pelajaran 2015/2016 pada materi pokok "Jagad Raya dan Tata Surya". Sebelum diterapkan pembelajaran dengan menggunakan konsep pembelajaran Gamification, dari 36 siswa kelas X5 terdapat 23 siswa yang minatnya masih kurang hal ini terlihat dari skor respon angket siswa yang masih dibawah skor minimal yang ditentukan yaitu 67 sehingga hanya 13 siswa yang minatnya tinggi atau skor angketnya mencapai skor minimal, sedangkan pada siklus I minat siswa sudah mulai meningkat yaitu dari jumlah siswa yang skor angketnya dibawah skor minimal yaitu 23 siswa pada kondisi awal menurun pada siklus I menjadi 10 siswa sehingga jumlah siswa yang minatnya tinggi bertambah menjadi 26 siswa dan pada siklus II minat belajar dari seluruh siswa kelas X5 sudah mengalami peningkat dengan rata-rata skor respon angket minat belajar siswa sudah di atas skor 67. Media pembelajaran interaktif sangat tepat untuk mengatasi permasalahan yang dijelaskan diatas. Media pembelajaran interaktif untuk mata pelajaran Biologi "Sistem Sirkulasi pada Manusia \& Sistem Pencernaan Makanan" akan mampu berkontribusi untuk membantu meningkatkan pemahaman siswa dalam pembelajaran biologi dan memudahkan guru dalam menjelaskan materi yang lebih variatif dan menyenangkan (Wiratama et al., 2015)

\section{KAJIAN TEORI}

A. Pembelajaran 
Kata media berasal dari bahasa latin medius yang secara harfiah berarti "tengah", "perantara", atau "pengantar". Dalam bahasa Arab, media adalah perantara atau pengantar pesan dari pengirim kepada penerima pesan (Arsyad, 2011). Pada pengertian lain, media adalah segala sesuatu yang dapat digunakan untuk menyampaikan pesan dari pengirim ke penerima pesan (Prawiradirga, 2008). Media adalah berbagai jenis komponen dalam lingkungan siswa yang dapat merangsangnya untuk belajar (Gagne, 1992). Senada dengan pendapat Gagne, Briggs mendefinisikan media pembelajaran sebagai bentuk fisik yang dapat menyajikan pesan yang dapat merangsang siswa untuk belajar. Dari dua definisi ini tampak pengertian media mengacu pada penggunaan alat yang berupa benda untuk membantu proses penyampaian pesan. Sementara itu Asosiasi Pendidikan Nasional (Nation Education Association/ NEA) memberikan batasan tentang media yaitu bentuk-bentuk komunikasi baik tercetak maupun audi visual serta bebagai peralatannya. Media pendidikan adalah sumber belajar dan dapat juga diartikan dengan manusia dan benda atau peristiwa yang membuat kondisi siswa mungkin memperoleh pengetahuan, keterampilan atau sikap.

\section{B. Metode Multimedia Development Life Cycle}

Pengembangan metode media pembelajaran multimedia interaktif ini dilakukan berdasarkan 6 tahap, yaitu, concept (pengonsepan), design (perancangan), material Collecting (pengumpulan bahan), assembly (pembuatan), testing (pengujian) dan distribution (pendistribusian). Ke enam tahapan ini tidaklah ahrus berurutan dalam praktiknya, tahaptahap tersebut dapat saling bertukar posisi, meskipun demikian, tahap concept memang harus menjadi hal pertama kali dikerjakan (Iwan Binato, 2010).

\section{Sistem Sirkulasi}

Sistem sirkulasi adalah sistem transportasi yang berfungsi untuk mengangkut berbagai zat di dalam tubuh. Sistem sirkulasi pada manusia dibagi menjadi dua, yaitu sistem peredaran darah dan sistem limfa.Sistem peredaran darah adalah sistem transportasi yang melibatkan tiga komponen, yaitu darah sebagai medium transportasi, jantung sebagai pemompa, dan pembuluh darah sebagai saluran. Sistem peredaran darah pada manusia bersifat tertutup dan ganda. Tertutup artinya, darah dialirkan melalui suatu pembuluh dan ganda artinya melewati jantung sebanyak dua kali.

\section{Sistem Pencernaan}

Berdasarkan prosesnya, pencernaan makanan dapat dibedakan menjadi dua macam seperti berikut. Proses mekanis, yaitu pengunyahan oleh gigi dengan dibantu lidah serta peremasan yang terjadi di lambung. Proses kimiawi, yaitu pelarutan dan pemecahan makanan oleh enzim-enzim pencernaan dengan mengubah makanan yang ber-molekul besar menjadi molekul yang berukuran kecil.Proses pencernaan makanan pada manusia terjadi di luar sel, disebut pencernaan ekstrasekuler. Sistem pencernaan manusia tersusun dari saluran pencernaan (mulut, faring, kerongkongan, lambung, usus halus, usus besar, dan anus) dan kelenjar pencernaan (hati dan pankreas).

\section{METODOLOGI PENELITIAN}

Penelitian ini merupakan jenis penelitian pengembangan multimedia interaktif pada materi sistem sirkulasi dan sistem pencernaan. Multimedia yang dihasilkan diuji validitas terlebih dahulu oleh ahli media pembelajaran, ahli isi materi pembelajaran, dan guru kelas, setelah media dinyatakan telah dapat diujicobakan kepada siswa maka diadakan uji respon siswa.

\section{A. Desain Penelitian}

Pengembangan media pembelajaran multimedia interaktif pada kelas XI mata pelajaran biologi dengan materi "Sistem Sirkulasi Pada Manusia dan Sistem Pencernaan Makanan" di SMA NEGERI 2 SINGARAJA". menggunakan model MDLC (Multimedia Development Life Cycle) media pembelajaran interaktif ini dilakukan berdasarkan 6 tahap, yaitu, concept (pengonsepan), design (perancangan), material Collecting (pengumpulan bahan), assembly (pembuatan), testing (pengujian) dan distribution (pendistribusian). Menurut Binanto (2010), ke enam tahapan ini tidaklah ahrus berurutan dalam praktiknya, tahap-tahap tersebut dapat saling bertukar posisi, meskipun demikian, tahap concept memang harus menjadi hal pertama kali dikerjakan. Berikut merupakan gambar tahapan metode MDLC.

\section{B. Tempat dan Waktu Penelitian}

Penelitian ini dilaksanakan di SMA N 2 Singaraja yang diadakan pada tahun pelajaran 2020/2021.

\section{Populasi dan Sampel Penelitian}

Populasi dalam penelitian ini adalah seluruh siswa kelas XI IPA 1 SMA N 2 Singaraja dan Sampel pada penelitian ini adalah seluruh kelas XI IPA 1 SMA N 2 Singaraja.

\section{Prosedur Penelitian}

Prosedur penelitian pengembangan media pembelajaran multimedia interaktif pada kelas XI Mata pelajaran Biologi dengan materi "Sistem Sirkulasi Pada Manusia dan Sistem Pencernaan Makanan" di SMA Negeri 2 Singaraja terdiri dari 6 tahap yakni concept (pengonsepan), design (perancangan), material Collecting (pengumpulan bahan), assembly (pembuatan), testing (pengujian) dan distribution (pendistribusian).

\section{E. Instrumen Penelitian}

Instrumen penelitian ini dengan memberikan 
kuesioner kepada ahli materi pelajaran yang terdiri dari dua orang, ahli media pembelajaran, dan uji respon siswa.

\section{F. Uji Validitas Media Pembelajaran \\ Uji validitas media menggunakan formula gregory yang menggunakan ahli isi mata pelajaran dan ahli media.}

\section{HASIL DAN PEMBAHASAN}

Pengembangan media pembelajaran multimedia interaktif pada kelas XI Mata Pelajaran Biologi Dengan Materi "Sistem Sirkulasi Pada Manusia dan Sistem Pencernaan" di SMA Negeri 2 Singaraja merupakan sebuah pengembangan dengan menggunakan metode $M D L C$. Metode $M D L C$ dipengembangan ini, terdiri dari 6 tahapan, yaitu Concept (pengonsepan), Design (perancangan), Material Collecting (pengumpulan bahan), Assembly (pembuatan), Testing ( pengujian) dan Distribution (distribusi). Metode MDLC merupakan model pengembangan yang bersifat universal dan mengkhusus pada pengembangan multimedia. Tahap-tahap pengembangannya yang sederhana, ringkas, padat dan bahkan antara tahapan Design dan Assembly dapat dilakukan paralel.

Tahap Concept, merupakan tahap pertama dari metode MDLC terkait Pengembangan media pembelajaran multimedia interaktif multimedia interaktif pada kelas XI Mata Pelajaran Biologi Dengan Materi "Sistem Sirkulasi Pada Manusia dan Sistem Pencernaan" di SMA Negeri 2 Singaraja ini, dimana ditahap pengonsepan ini bertujuan untuk menyederhanakan dan memfokuskan suatu gagasan yang sudah ditetapkan. Adapun gagasan yang diterapkan seperti; (1) judul yang akan diangkat, (2) sasaran pengguna media pembelajaran, (3) tujuan dari media pembelajaran, (4) jenis media yang akan diangkat, (5) pedoman materi/buku/ yang digunakan, (6) kosep materi sitem sirkulasi dan sistem pencernaan yang diangkat dalam media pembelajaran, (7) kurikulm yang diupergunakan dalam pengembangan, (8) cara/teknik pembuatan media pembelajaran, (9) type format gambar, audio dan video yang digunakan dalam proses pengembangan film, (10) software yang digunakan, dan (11) output dari pengembangan.

Tahap kedua yaitu tahap design (perancangan), tahap ini meliputi perancangan media pembelajaran yang akan dikembangkan, dimana peneliti melakukan perancangan desain skenario dan gamifikasi. Perancangan skenario menyesuaikan dengan masalah atau konsep materi sirkulasi dan sistem pencernaan yang akan dipelajari, sehingga antara skenario media pembelajaran dengan topik yang dibahas bisa seimbang dan sesuai. Perancangan desain gamifikasi berada di akhir pembelajaran saat melakukan evaluasi. Kolaborasi dengan konsep gamifikasi yang di akhir pembelajaran terdapat permainan kecil yang akan merefleksi pikiran siswa dengan cara bermain akan tetapi tidak sedikitpun mengurangi pembahasan dengan materi yang diawal dijelaskan.

Tahap ketiga yaitu tahap material collecting (pengumpulan bahan). Pada tahap pengumpulan bahan ini, peneliti menggunakan berbagai bahan yang sudah tersedia dari website penyedia yang free dan berlisensi. Pada tahap pengumpulan bahan, bahan yang dikumpulkan adalah berupa teks, gambar, animasi, suara dan mengumpulkan bahanbahan materi dan soal-soal yang akan ditampilkan dalam media pembelajaran. Bahan bahan yang digunakan untuk kebutuhan aplikasi diperoleh dari membuat sendiri dengan menggunakan Adobe Photoshop CS6, Adobe Flash Profesional CS6, Adobe Audition, Adobe Ilustrator, Adobe Adobe Primerex Pro, Adobe After Effects, serta beberapa bahan yang diambil dari internet yang kemudian diolah dengan sotware yang telah disebutkan sebelumnya.

Tahap ke-empat yaitu tahap Assembly (pembuatan), pada tahap pembuatan animasi ini dimulai sesuai rancangan yang dibuat sebelumnya, Tahap asembly merupakan bagian dari kegiatan produksi animasi, penyusunan teks, dan lain-lain. Pada tahap ini, media pembelajaran mulai dikembangkan sesuai dengan yang sudah ditetapkan pada tahap design. Pembuatan atau proses produksi media pembelajaran interaktif, membutuhkan alur kerja produksi yang teratur dan sistematis agar waktu produksi bisa berjalan lebih efektif dan juga tepat sasaran, sesuai dengan target waktu yang direncanakan. Pada tahap ini peneliti melakukan langkah langkah pembuatan media pembelajaran dari tahap mendesain background menggunakan aplikasi adobe photosop cs6, kemudian tahap pembuatan materi berupa video peneliti menggunakan aplikasi adobe after effect cs6, ketika kedua tahap tersebut sudah selesai maka lanjut ke proses penggabungan. Pada tahap ini peneliti menggunakan aplikasi Adobe Flash CS6 untuk menggabungkan semua bahan yang sudah dibuat sebelumnya dan memberikan fitur fitur animasi, sound, dubbing maupun tombol yang akan digunakan

Pada tahap Testing dilakukan Pengujian media pembelajaran interaktif. Pengujian ini merupakan proses menjalankan dan mengevaluasi sebuah media pembelajaran untuk menguji apakah media tersebut sudah memenuhi persyaratan atau belum, untuk menentukan perbedaan antara hasil yang diharapkan dengan hasil sebenarnya. Pada tahap pengujian ini uji ahli yang pertama dilakukan adalah uji ahli isi pembelajaran. Setelah melakukan uji ahli isi, kemudian dilanjutkan dengan uji ahli media dan terakhir untuk uji respon siswa.

Setelah melalui tahap pengujian para ahli, didapatkan hasil uji ahli isi materi pembelajaran dengan hasil perhitungan 1 menunjukkan kriteria "Sangat Tinggi" dan hasil uji ahli media dengan hasil perhitungan 0.88 menunjukkan pada kriteria " Tinggi”. Rata-rata hasil perhitungan uji ahli mendapatkan hasil 1 \& 0.88 
menunjukkan pada kriteria "Valid". Validitas produk dapat dilakukan oleh beberapa pakar atau tenaga ahli yang sudah berpengalaman untul menilai kelemahan dan kekuatan produk yang dihasilkan agar suatu produk dapat digunakan sesuai dengan tujuannya (Sugiyono, 2010)

Hasil penilaian ahli isi dengan mengunakan uji Gregory berdasarkan angket menunjukkan bahwa tingkat pencapaian dari media pembelajaran adalah "Sangat Tinggi" dan layak untuk dilanjutkan. Hal tersebut mengindikasikan bahwa materi pelajaran yang diimplementasikan dalam media pembelajaran sudah relevan untuk digunakan dalam pembelajaran Biologi dengan materi sistem sirkulasi dan sistem pencernaan pada siswa kelas XI SMA. Materi pelajaran yang memadukan sajian materi dari beberapa sumber buku sebagai referensi pembelajaran dinyatakan valid dan sudah sesuai dengan indikator dan tujuan pembelajaran pada silabus Biologi materi sirkulasi dan sistem pencernaan. Hasil penilaian uji ahli media berdasarkan angket menunjukkan bahwa tingkat pencapaiannya adalah "Tinggi", namun ada beberapa saran perbaikan dari penguji untuk melakukan perbaikan pada pengembangan media pembelajaran. saran tersebut sudah dipaparkan pada fase pengujian. Setelah itu dilakukan revisi oleh peneliti untuk menyempurnakan pengembangan media pembelajaran

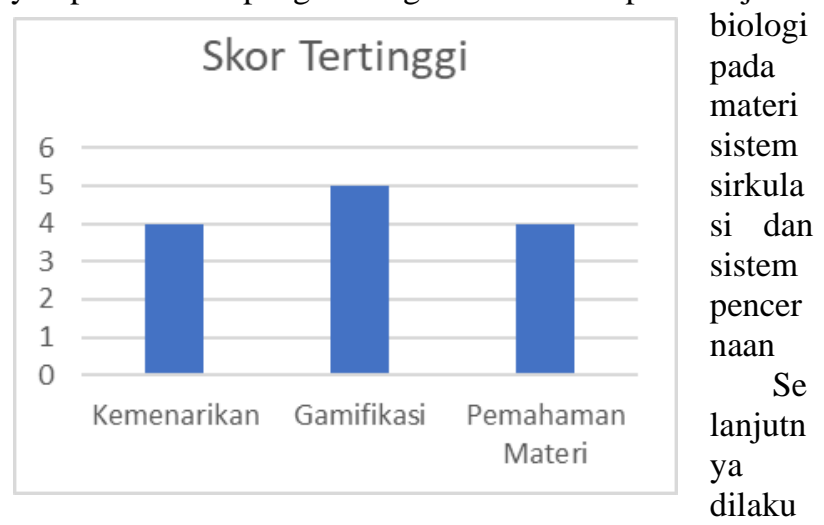

kan uji respon siswa, responden yang digunakan sebanyak 26 orang siswa kelas XI MIPA I SMA Negeri 2 Singaraja memperoleh rata-rata dari semua responden mendapatkan hasil 4.07 Kemudian peneliti mengubah rata - rata tersebut menjadi hasil persentase agar sesuai dengan tabel kriteria uji respon siswa. Setelah dikonversi ke dalam persentasi didapatkan hasil $81 \%$. Jika dikategorikan ke dalam tabel konversi termasuk dalam kategori "Baik". Hal ini menunjukkan keberhasilan media pembelajaran interaktif pada kelas XI Mata Pelajaran Biologi Dengan Materi "Sistem Sirkulasi Pada Manusia dan Sistem Pencernaan" di SMA Negeri 2 Singaraja dengan baik, yang dibuktikan dengan terbantunya siswa dalam proses pembelajaran, mempermudah proses guru menjadi mudah membawakan materi pembelajaran, siswa sudah tidak cepat merasa jenuh saat pembelajaran, dan diharapkan bisa meningkatkan motivasi siswa dalam pembelajaran Biologi.

\section{Gambar 1. GrafikBar Chart Respon Siswa \\ Terhadap Media Pembelajar}

Secara umum hasil uji efektivitas 26 siswa sebagai responden memberikan komentar yang positif terhadap media pembelajaran biologi tersebut, rata - rata mereka berkomentar (1) siswa sangat senang belajar dengan media pembelajaran interaktif ini, (2) Siswa dapat memahamimateri pelajaran dengan baik, (3) menarik minat siswa untuk belajar, dan (4) materi yang disajikan berbentuk video sangat menarik perhatian. Berikut ini adalah gambar grafik bar chart respon siswa terhadap media pembelajaran

Selanjutnya tahap Distribution, media animasi di tempatkan pada suatu media penyimpanan, pendistribusian media dilakukan dengan menggunakan media DVD (digital versatile discs), penggunaan media DVD dipilih karena pada VCD lapisan data terletak di bawah dan bersentuhan langsung dengan label. Sedangkan lapisan data yang ada di DVD terletak di tengah-tengah keping. Hal ini mengakibatkan, data yang ada di VCD bisa hilang bila label yang ada di VCD terkelupas oleh goresan tangan ataupun benda lainnya. Selain itu DVD memiliki ukuran pit lebih kecil dari CD. Pit adalah lubang (galian) kecil atau tekanan yang sedikit di atas permukaan disc yang mengijinkan pickup laser untuk membedakan antara kondisi digital berlogik 0 dan 1. DVD sisi tunggal, lapisan tunggal dapat menyimpan sekitar tujuh kali lebih.

Adapun hambatan dalam pembuatan produk multimedia interaktif pada kelas XI Mata Pelajaran Biologi Dengan Materi "Sistem Sirkulasi Pada Manusia dan Sistem Pencernaan" di SMA Negeri 2 Singaraja adalah pada tahap pengumpulan materi pembelajaran dikarenakan kata-kata ilmiah yang terdapat dalam pembelajaran Biologi harus dipahami sehingga antara kata dan gambar sesuai dan tidak terjadi salah persepsi, hal tersebut dapat diatasi dengan menanyakan kata-kata ilmiah tersebut kepada guru mata pelajaran Biologi dan kesulitan lainnya adalah dalam pembuatan soal-soal evaluasi yang harus sesuai dengan materi pembelajaran pada media pembelajaran, sehingga solusi yang dapat dilaksanakan yakni menanyakan kepada guru mata pelajaran Biologi di sekolah bersangkutan dan kepada dosen ahli mata pelajaran Biologi di Universitas Pendidikan Ganesha, setelah melaksanakan konsultasi, perbaikan, mendapatkan nilai dari para ahli serta memperoleh uji respon siswa, maka hasil penelitian pengembangan ini adalah multimedia interaktif pada kelas XI Mata Pelajaran Biologi Dengan Materi "Sistem Sirkulasi Pada Manusia dan Sistem Pencernaan" di SMA Negeri 2 Singaraja sejalan hasil penelitian berikut yakni media pembelajaran ini lebih banyak didominasi teks, suara, gambar \& animasi. Media yang dikembangkan memiliki keunggulan dari tampilan, background, hingga dilengkapi dengan animasi berupa simulasi dan dapat memudahkan guru untuk mengetahui hasil dari tugas siswa karena dapat langsung mencetak hasil kerja 
siswa. Simpulan yang didapat, perangkat ajar Macromedia Flash Profesional 8 untuk materi Sistem Ekskresi pada Manuasia di SMP Negeri 1 Tambusai Utara merupakan aplikasi yang sangat layak digunakan oleh guru dan siswa (Hamdani et al., 2016)

Penelitian selanjutnya menghasilkan penelitian pengembangan multimedia pada materi abjad dan angka dengan model MDLC yang memperoleh hasil bahwa multimedia yang dirancang secara menarik akan membangkitkan motivasi dan rangsangan kegiatan belajar peserta didik, membantu peserta didik meningkatkan pemahaman materi pembelajaran serta menumbuhkan kreativitas belajar sehingga akan berdampak pada peningkatan kualitas pembelajaran (Sugiarto, 2018).

Pengembangan media pembelajaran biologi berbasis Adobe Flash Pada Materi Pembelahan Sel Kelas XII SMA NEGERI 1 SUNGAI RAYA". Tujuan penelitian pengembangan media pembelajaran berbasis adobe flash ini adalah untuk meningkatkan kualitas pembelajaran didalam kelas, merangsang pikiran, perasaan dan perhatian peserta didik agar lebih memahami materi yang sedang dijelaskan oleh guru. Metode penelitian pada penelitian ini adalah pengembangan atau Research and Development (R\&D), menggunakan pengembangan media pembelajaran 4-D dengan 4 Tahapan yaitu : pendefinisian (Define), perancangan (Design), pengembangan (Develop), namun tanpa penyebaran (Disseminate) karena keterbatasan waktu \& biaya. Penelitian ini dilakukan di SMA NEGERI 1 SUNGAI RAYA kels XII IPA 5 dengan uji coba 2 skala yaitu skala kecil dan skala besar. Respon siswa pada uji coba skala kecil dilakukan oleh 15 siswa sedangkan uji coba skala besar dilakukan oleh 30 siswa. Metode yang digunakan untuk pengumpulan data adalah angket, angket tersebut yang diberikan bentuk skala linkert. Pada penelitian ini didapatkan memenuhi aspek kevalidan media pembelajaran adobe flash dengan hasil validasi materi rata-rata $85,93 \%$ (sangat valid) dan validasi media rata-rata 88,97 (sangat valid). Respon dari siswa untuk media pembelajaran adobe flash pada tahap uji coba skala kecil rata-rata persentase $80,5 \%$ (sangat kuat) sedangkan pada uji coba skala besar rata-rata persentase $(87,42 \%)$ sangat kuat. Dengan demikian dapat disimpulkan media pembelajaran adobe flash layak digunakan sebagai media dalam proses pembelajaran karena setiap aspek penilaian keseluruhan memiliki kriteria positif dan respon siswa mendapatkan kategori sangat valid \& kuat (Eka \& Setiadi, 2017).

Penelitian selanjutnya memaparkan bahwa penerapan Konsep Gamification untuk Meningkatkan Minat dan Partisipasi Siswa pada Mata Pelajaran Geografi di SMA NEGERI 2 SALATIGA" Mata pelajaran Geografi merupakan salah satu pelajaran yang terdiri dari banyak materi. Dalam pembelajaran Geografi, banyaknya materi harus dipelajari berupa hafalan yang membuat siswa jenuh terhadap pembelajaran Geografi. Gamification adalah sebuah proses yang bertujuan mengubah non-game context (contoh: belajar, mengajar, pemasaran, dan lain sebagainya) menjadi jauh lebih menarik dengan

mengintegrasikan game thinking, game design, dan game mechanics. Berdasarkan pembahasan analisis data yang telah dilakukan dalam penelitian maka dapat disimpulkan sebagai berikut: Penggunaan konsep pembelajaran Gamification dapat meningkatkan minat dan partisipasi belajar siswa pada mata pelajaran Geografi kelas X5 di SMA Negeri 2 Salatiga Semester I Tahun Pelajaran 2015/2016 pada materi pokok "Jagad Raya dan Tata Surya". Sebelum diterapkan pembelajaran dengan menggunakan konsep pembelajaran Gamification, dari 36 siswa kelas X5 terdapat 23 siswa yang minatnya masih kurang hal ini terlihat dari skor respon angket siswa yang masih dibawah skor minimal yang ditentukan yaitu 67 sehingga hanya 13 siswa yang minatnya tinggi atau skor angketnya mencapai skor minimal, sedangkan pada siklus I minat siswa sudah mulai meningkat yaitu dari jumlah siswa yang skor angketnya dibawah skor minimal yaitu 23 siswa pada kondisi awal menurun pada siklus I menjadi 10 siswa sehingga jumlah siswa yang minatnya tinggi bertambah menjadi 26 siswa dan pada siklus II minat belajar dari seluruh siswa kelas X5 sudah mengalami peningkat dengan rata-rata skor respon angket minat belajar siswa sudah di atas skor 67 (Wiratama et al., 2015)

Penelitian selanjuutnya memaparkan perancangan Media Pembelajaran Fisika SMP Berbasis Multimedia Interaktif menempati posisi yang cukup penting sebagai salah satu komponen sistem pembelajaran. Sehingga perlu dibuat sebuah aplikasi media pembelajaran berbasis multimedia interaktif yang dapat meningkatkan perhatian siswa terhadap materi pembelajaran . Tujuan penelitian ini adalah merancang aplikasi Media pembelajaran Fisika SMP Berbasis Multimedia Interaktif dengan materi getaran dan gelombang. Metodologi yang digunakan adalah Multimedia Development Life Cycle (MDLC). Diawali dengan pembuatan konsep, kemudian merancang struktur navigasi, implementasi, serta melakukan pengujian black box .Hasil penelitian berupa aplikasi memuat menu login, menu utama ,menu SK/KD, menu Tujuan, menu Indikator, menu Materi dan Evaluasi, serta dilengkapi simulasi animasi materi. Aplikasi berjalan baik dengan keluaran berekstensi .swf dan .exe yang dapat dijalankan dengan flash player. hasil dari penelitian ini adalah aplikasi media pembelajaran fisika berbasis multimedia interaktif untuk kelas VIII Sekolah Menengah Pertama ,dengan materi getaran dan gelombang, telah berhasil dirancang dan dibangun menggunakan adobe flash cs6, serta dapat berjalan baik dengan ekstensi file.swf (Rosyidi, 2011)

\section{SIMPULAN DAN SARAN}

Berdasarkan hasil penelitian dan pembahasan pada penelitian Pengembangan media pembelajaran multimedia 
e-ISSN: 2685-7006|p-ISSN: $2252-9063$

Kumpulan Artikel Mahasiswa Pendidikan Teknik Informatika

(KARMAPATI)

Volume 10, Nomor 3, Tahun 2021

interaktif multimedia interaktif pada kelas XI Mata Pelajaran Biologi Dengan Materi "Sistem Sirkulasi Pada Manusia dan Sistem Pencernaan" di SMA Negeri 2 Singaraja maka penulis dapat menarik kesimpulan sebagai berikut.

Pengembangan media pembelajaran multimedia interaktif pada kelas XI Mata Pelajaran Biologi Dengan Materi "Sistem Sirkulasi Pada Manusia dan Sistem Pencernaan" di SMA Negeri 2 Singaraja menggunakan beberapa aplikasi diantaranya dapat dijadikan sebagai penunjang proses pembelajaran dalam mempelajari materi biologi sistem sirkulasi pada manusia dan sistem pencernaan makanan.

Respon pengguna yaitu siswa media pembelajaran multimedia interaktif pada kelas XI Mata Pelajaran Biologi Dengan Materi "Sistem Sirkulasi Pada Manusia dan Sistem Pencernaan" di SMA Negeri 2 Singaraja mendapatkan respon yang baik, mereka sangat tertarik dan antusias untuk melihat dan mempelajari materi sistem sirkulasi dan sistem pencernaan dengan cara menonton media pembelajaran yang di tampilkan. Uji respon siswa, responden yang digunakan sebanyak 26 orang siswa kelas XI MIPA I SMA Negeri 2 Singaraja. Rata-rata penilaian siswa setelah dihitung secara keseluruhan adalah $81.4 \%$. Jika dikategorikan ke dalam tabel konversi termasuk dalam kategori "Baik". Hal ini menunjukkan keberhasilan multimedia interaktif pada kelas XI Mata Pelajaran Biologi Dengan Materi "Sistem Sirkulasi Pada Manusia dan Sistem Pencernaan" baik, yang dibuktikan dengan terbantunya siswa dalam proses pembelajaran mempermudah proses, gur menjadi mudah membawakan materi pembelajaran, siswa sudah tidak cepat merasa jenuh saat pembelajaran, dan diharapkan bisa meningkatkan motivasi siswa dalam pembelajaran Biologi. Berdasarkan pengamatan peneliti di lapangan, terdapat beberapa hal yang dapat dijadikan bahan pertimbangan untuk pengembangan berikutnya. Di antaranya adalah sebagai berikut: 1. Media ini masih memiliki keterbatasan pada materi sehingga untuk pengembangan selanjutnya materi sistem sirkulasi dan sistem pencernaan dapat diperdalam dan diperbanyak untuk memberikan pengetahuan yang lebih dalam untuk pelajaran Biologi. 2. Media ini masih memiliki kekurangan pada fitur - fitur, belum adanya fitur pengaturan tinggi rendahnya suara (volume) pada media pembelajaran ini, sehingga pengembangan selanjutnya agar melengkapi fitur - fitur yang belum ada pada saat ini.3. Evaluasi dengan menggunakan konsep gamifikasi masih berbentuk permainan sederhana, untuk pengemembangan selanjutnya diharapkan mampu menambah level permainan dari yang ada sebelumnya agar lebih menarik perhatian.

\section{DAFTAR PUSTAKA}

Arsyad, A. (2011). Media Pembelajaran. PT Raja Grafindo Persada.

Eka, E., \& Setiadi, A. E. (2017). Pengembangan Media Pembelajaran Biologi Berbasis Adobe Flash Pada Materi Sel Kelas XII SMA Negeri 1 Sungai Raya.
Bioeducationa, 2(1), 15-24 http://openjurnal.unmuhpnk.ac.id/index.php/bioed/articl e/view/664/541

Gagne. (1992). Principles of Intructional Design. Holt.Reihha.

Hamdani, R., Karno, R., \& Afifah, N. (2016). Pengembangan Media Pembelajaran Biologi Dengan Menggunakan Macromedia Flash Profesional. Urnal Ilmiah Edu Research, 4(1), 283. https://ejournal.upp.ac.id/index.php/EDU/article/view/1198/pdf $-43$

Iwan Binato. (2010). Mulyimedia Teori (Yogyakarta). Pustaka Nasional.

Prawiradirga. (2008). Prinsip-prinsip Desain Pembelajaran. Kencana.

Rosyidi. (2011). Pengantar Teori Ekonomi Pendekatan Kepada Teori Ekonomi Makro. Rajagrafindo Persada.

Sugiarto, H. (2018). Penerapan Multimedia Development Life Cycle Pada Aplikasi Pengenalan Abjad Dan Angka. IJCIT (Indonesian Journal on Computer and Information Technology), 3(1), 26-31. https://doi.org/https://doi.org/10.31294/ijcit.v3i1.3753

Sugiyono. (2010). Metode Penelitian Pendidikan (Pendekatan Kuantitatif, Kualitatif, dan $R \& d$ ). Alfabeta.

Wiratama, Anggar, Jasson, \& George. (2015). Penerapan Konsep Gamification Untuk Meningkatkan Minat Dan Partisipasi Siswa Pada Mata Pelajaran Geografi Di Sma Negeri 2 Salatiga. Universitas Satya Wacana. 